Article

\title{
Exploring the Effect of Increased Energy Density on the Environmental Impacts of Traction Batteries: A Comparison of Energy Optimized Lithium-Ion and Lithium-Sulfur Batteries for Mobility Applications
}

\author{
Felipe Cerdas $1,3, *$ (D), Paul Titscher ${ }^{2,3}$ (D), Nicolas Bognar ${ }^{1,3}$, Richard Schmuch ${ }^{4}$ (D), \\ Martin Winter 4,5, Arno Kwade 2,3 (D) and Christoph Herrmann 1,3 \\ 1 Chair of Sustainable Manufacturing \& Life Cycle Engineering, Institute of Machine Tools and Production \\ Technology (IWF), Technische Universität Braunschweig, Langer Kamp 19b, 38106 Braunschweig, Germany; \\ n.bognar@tu-braunschweig.de (N.B.); c.herrmann@tu-braunschweig.de (C.H.) \\ 2 Institute for Particle Technology (iPAT), Technische Universität Braunschweig, Volkmaroder Straße 5, \\ 38104 Braunschweig, Germany; p.titscher@tu-braunschweig.de (P.T.); a.kwade@tu-braunschweig.de (A.K.) \\ 3 Battery LabFactory Braunschweig (BLB), Technische Universität Braunschweig, Langer Kamp 19, \\ 38106 Braunschweig, Germany \\ 4 MEET Battery Research Center, Institute of Physical Chemistry, University of Münster, Corrensstraße 46, \\ 48149 Münster, Germany; richard.schmuch@uni-muenster.de (R.S.); mwint_01@uni-muenster.de (M.W.) \\ 5 Helmholtz Institute Münster, IEK-12, Forschungszentrum Jülich GmbH, Corrensstraße 46, \\ 48149 Münster, Germany \\ * Correspondence: juan.cerdas-marin@tu-braunschweig.de; Tel.: +49-531-391-7177; Fax: +49-391-5842
}

Received: 21 December 2017; Accepted: 4 January 2018; Published: 8 January 2018

\begin{abstract}
The quest towards increasing the energy density of traction battery technologies has led to the emergence and diversification of battery materials. The lithium sulfur battery (LSB) is in this regard a promising material for batteries due to its specific energy. However, due to its low volumetric energy density, the LSB faces challenges in mobility applications such as electric vehicles but also other transportation modes. To understand the potential environmental implication of LSB batteries, a comparative Life Cycle Assessment (LCA) was performed. For this study, electrodes for both an NMC111 with an anode graphite and a LSB battery cell with a lithium metal foil as anode were manufactured. Data from disassembly experiments performed on a real battery system for a mid-size passenger vehicle were used to build the required life cycle inventory. The energy consumption during the use phase was calculated using a simulative approach. A set of thirteen impact categories was evaluated and characterized with the ReCiPe methodology. The results of the LCA in this study allow identification of the main sources of environmental problems as well as possible strategies to improve the environmental impact of LSB batteries. In this regard, the high requirements of $\mathrm{N}$-Methyl-2-pyrrolidone (NMP) for the processing of the sulfur cathode and the thickness of the lithium foil were identified as the most important drivers. We make recommendations for necessary further research in order to broaden the understanding concerning the potential environmental implication of the implementation of LSB batteries for mobility applications.
\end{abstract}

Keywords: lithium-ion batteries; post lithium-ion batteries; lithium-sulfur batteries; life cycle assessment; electric vehicles 


\section{Introduction}

\subsection{Background and Motivation of the Study}

Transport of goods and people brings numerous challenges to the global agenda concerning sustainability. On the one hand, transport is responsible for $25 \%$ of air pollution due to particulate matter in urban areas causing important human health impacts [1]. On the other hand, in 2013 the transport sector was responsible for over $23 \%$ of the overall energy-related greenhouse gas (GHG) emissions, $75 \%$ of which was particularly caused by road transport [2]. The international energy agency (IEA) estimated that the transportation sector could potentially achieve a reduction of $18 \%$ of GHG until 2050 [3]. In this regard, electric vehicles (EVs) offer several attractive advantages. EVs do not only produce no tailpipe emissions, they also operate at a power train efficiency ranging between $60 \%$ to $80 \%$ [4] in comparison to a $20 \%$ to $35 \%$ for internal combustion engine vehicles (ICEVs). As Hawkins and colleagues reported [5], assuming an average European electricity mix and a vehicle lifetime of 150,000 km, EVs present a reduced global warming potential (GWP) by approximately $20 \%$ compared to ICEVs based on a cradle to grave analysis. Unlike ICEVs, EVs rely solely on a battery system to store the complete energy required by the vehicle not only for propulsion, but also for numerous auxiliary functions such as on-board electronics, lighting, heating and air conditioning. The battery system of an EV plays a determinant role towards a successful implementation of electric mobility and the reduction of the life cycle environmental impacts compared to ICEVs. On the one side, a widespread adoption of EVs depends on the capability of the battery technology to increase energy and power density and prolong its lifetime while decreasing its cost [6]. On the other side, current commercial traction batteries are heavy and expensive devices that consist of raw materials, which are high in embodied energy (e.g., aluminum, copper, nickel, cobalt, graphite) [7]. These factors combined together with an increase in the demand for more capable energy storage systems technology, have motivated the rise of research efforts striving to overcome the technological boundaries on energy capacity and cost $[6,8,9]$. New energy storage systems imply changes in the material supply chains and production. Research regarding the environmental impact of battery systems for mobility applications is still an emerging field. Particularly the environmental assessment of emerging battery technologies remains, with very few exceptions, unexplored. In this paper, we explore the effect of increasing energy density to the environmental impacts of traction batteries for electromobility. Specifically, we studied the life cycle environmental impact of lithium sulfur batteries (LSB). In order to benchmark the results of our study, we estimated the life cycle environmental impacts of a lithium-ion battery (LIB) as this technology offers already a set of suitable characteristics for the mobility sector and is considered to be the reference point when comparing other technologies [8]. In this regard, we have modeled and calculated the environmental impacts of an NMC111/graphite battery system.

\subsection{Towards Higher Energy Density Batteries: Lithium-Ion and Lithium Sulfur Batteries}

Improvements in energy density and specific energy can be achieved mainly by: (i) optimizing the design, weight and integration of peripheral (inactive) components at cell and battery pack level; (ii) optimizing current active materials and (iii) developing of new active materials [6,8-11]. The LIB technology has achieved specific energy values of over $250 \mathrm{Wh} / \mathrm{kg}$ and energy density values as high as $697 \mathrm{Wh} / \mathrm{L}$ [8]. LIBs have been widely adopted and currently dominate both portable electronic devices and the electric vehicle market [8]. Among the different LIB technologies available, NMC-type layered oxides $\left(\mathrm{LiNi}_{1-x-y} \mathrm{Mn}_{y} \mathrm{Co}_{x} \mathrm{O}_{2}\right)$ are one of the most established positive electrode material in EVs as is evaluated in [12-16]. Research towards the improvement of NMC cathode materials have focused on the optimization of its specific energy by both increasing the amount of nickel and lithium within the cathode slurry [9]. The state of the art material used for the current generation of EVs is NMC $622(60 \% \mathrm{Ni}, 20 \% \mathrm{Co}$ and $20 \% \mathrm{Mn})$ and the aim of current research is to increase the Ni content, while substituting further by simultaneously decreasing Co and Mn [8]. In addition to current LIBs, many other battery chemistries are promising regarding a potential improvement of the specific energy 
and energy density. These alternative technologies, also called post lithium ion batteries (PLIBs), are currently under active research since there is a common agreement in the literature that the limits of specific energy and energy density of current LIBs might soon be reached as reviewed by Placke and colleagues [8]. In this regard, the lithium sulfur (LSB) batteries are considered as a promising battery technology for future EVs [17] and even for other mobile applications such as space and aviation [18]. This results from a high theoretical specific energy of approximately $2500 \mathrm{Wh} / \mathrm{kg}$ [19]. Especially in terms of the specific energy lithium-sulfur cells are promising for weight sensitive application areas, such as aviation [18]. Approximately $350-400 \mathrm{Wh} / \mathrm{kg}$ are currently achievable in prototype cells and up to $600 \mathrm{Wh} / \mathrm{kg}$ on cell level are expected [20-22]. Sulfur, compared to the active materials commonly used for the lithium-ion technology, has a low density $\left(2.07 \mathrm{~kg} / \mathrm{m}^{3} \mathrm{vs} . \sim 4.7 \mathrm{~kg} / \mathrm{m}^{3}\right.$ of NMC) [6]. This implies both an advantage and a disadvantage. On the one side, LSB offers the chance to manufacture batteries with a higher specific energy (i.e., able to store more energy per kilogram of battery). On the other side, LSB batteries have a lower volumetric energy density, which means that it requires more space per unit of energy stored. This is particularly critical in mobility applications, where the use of volume for technical components needs to be optimized. In any case, in order to take advantage (or reduce its volumetric disadvantage) of the characteristics offered by the LSB technology, all the other components within the cell have to be as light as possible. Inactive masses, such as housing and current collectors, as well as the amount of electrolyte and conductivity additives or sulfur host material has a big lever with regard to the overall cell mass $[8,22]$. Therefore, structurally integrated battery concepts have the potential to save inactive mass. Furthermore, the other components besides the sulfur cathode, such as the lithium metal anode, separator and electrolyte and its amount, have to be optimized to meet the requirements of power, specific energy and cycle life [23-29].

\subsection{Life Cycle Assessment (LCA) and Its Application for Traction Batteries}

LCA is a system analysis methodology standardized by ISO 14040, which enables the estimation of environmental impacts of product systems on a life cycle perspective [30,31]. It starts with the definition of the system boundaries and the selection of a functional unit, followed by a comprehensive collection of inventory data. Information regarding material and energy flows as well as emissions generated is gathered for all relevant phases in the supply chain of the product. These flows are then linked to potential environmental impacts through the application of impact pathway models that allow accounting for environmental effects (e.g., acidification and global warming) and, further, for ecological damages to the so-called areas of protection (e.g., ecological systems, natural resources and human health) [32]. Although the methodology faces several challenges, such as data availability and uncertainty, it can provide relevant insights to develop consistent strategies to reduce the environmental impact of technology and to avoid shifting environmental concerns from one life cycle stage to another within the supply chain. An overview of the application of the LCA methodology for the analysis of electric vehicles can be consulted in $[33,34]$. Numerous studies have addressed the environmental dimension of EVs [33,35-41]. The production phase has been identified in the literature to account for about half of the lifecycle GWP impact of EVs. Furthermore, all reviewed studies estimated that around $40-50 \%$ of the total GHG produced during this stage are caused by the production of the battery system $[5,42-46]$. In other impact categories such as human toxicity, ecotoxicity, eutrophication and metal depletion the battery system represents the largest contribution $[5,33]$. Nevertheless, only few studies have addressed in detailed the impact of the traction battery [7,12-14,36]. Current LCA studies on traction battery systems have accounted for cradle to gate GWP results ranging from 39-196 kg $\mathrm{CO}_{2}$-eq/kWh as shown in Table 1 . The variation in the results obey mainly differences in the cell chemistry of the battery system being analyzed and to the different assumptions to build the life cycle inventories. A study conducted by Kim et al. uses primary data from a large scale battery production site to evaluate a real $\mathrm{LiMn}_{2} \mathrm{O}_{4}$ (LMO)/NMC with a capacity of $24 \mathrm{kWh}$ batteries [12]. In their result, they estimated $140 \mathrm{~kg} \mathrm{CO}$-eq/ $\mathrm{kWh}$. In general, batteries that contain nickel and cobalt have a higher cradle-to-gate energy intensity and results in higher GHG emissions than others such as LiFePO4 (LFP) 
and LMO [7]. In literature, only one study rates the environmental impact of LSB traction batteries. Deng et al. performed a LCA of LSB batteries for a graphene sulfur composite cathode and a lithium metal anode [47]. Data for the life cycle inventory is derived from a lab-scale battery production and literature, specifically the BatPac model 3.0, to deduce a battery pack of $61.3 \mathrm{kWh}$ and a weight of $279 \mathrm{~kg}$.

Table 1. Comparison of literature data.

\begin{tabular}{|c|c|c|c|c|}
\hline Author & Battery Chemistry & Battery Size (kWh) & $\begin{array}{c}\text { Battery Pack Specific } \\
\text { Energy (kWh//kg }\end{array}$ & $\begin{array}{c}\text { Cradle-to-Gate GWP (kg } \\
\mathrm{CO}_{2}-\mathrm{eq} / \mathrm{kWh} \text { battery }\end{array}$ \\
\hline Notter et al. 2010 [48] & LMO_graphite & 34.2 & 0.114 & 53 \\
\hline Zackrisson et al. 2010 [49] & LFP_graphite & 10.0 & 0.093 & 160 \\
\hline Majeau-Bettez 2011 [13] & $\begin{array}{l}\text { NiMH, NMC, } \\
\text { LFP_graphite }\end{array}$ & $24.0^{\mathrm{a}}$ & $0.112^{a}$ & $196^{\mathrm{a}}$ \\
\hline Dunn et al. 2012 [50] & LMO_graphite & 28.0 & 0.133 & 39 \\
\hline Ellingsen et al. 2013 [14] & NMC_-graphite & 26.6 & 0.105 & 172 \\
\hline Kim et al. 2016 [12] & LMO/NMC - graphite & 24.0 & 0.08 & 140 \\
\hline Deng et al. 2017 [47] & LSB & 61.3 & 0.22 & 146 \\
\hline Peters et al. 2016 [51] & Na-ion & n.a. & 0.102 & 140 \\
\hline
\end{tabular}

Their results show a relative environmental advantage the LSB battery compared to the conventional NMC-based battery system as described by Ellingsen et al. [14]. In their study, the specific $\mathrm{CO}_{2}$-emissions per $\mathrm{km}$ of the LSB battery were estimated to be approximately $10 \%$ below those of the NMC-based LIB (158 g vs. $174 \mathrm{~g} \mathrm{CO}_{2}$-eq per $\mathrm{km}$ for the LIB). In their study, the authors assumed a decay rate of $0.028 \%$ capacity loss per cycle. The battery lifetime in consequence exceeds $200.000 \mathrm{~km}$ for the LSB battery system, which is not realistic today. The sensitivity analysis in this work indicates a critical dependency of the results to the decay rate of the battery capacity. Peters et al. [51] studied the environmental impacts of a sodium-ion battery system. An energy density of $102 \mathrm{Wh} / \mathrm{kg}$ on pack level with a battery cycle life of 2000 cycles was assumed. The resulting impact of the battery production on climate change is $140 \mathrm{~kg} \mathrm{CO}$-eq/ $\mathrm{kWh}$ and comparable to LIB results. In other impact categories such as eutrophication and human toxicity, they outperform current LIB batteries. Energy densities found in today LIB battery packs range from $90-140 \mathrm{kWh} / \mathrm{kg}$. The energy required in the manufacturing phase of battery cells is one of the main discussion points throughout the LCA literature on traction batteries. As mentioned in the previous section, the energy demand during the manufacturing phase of the battery cells reported in the literature varies extremely. For instance, Ellingsen and colleagues reported a minimum demand of around $4330 \mathrm{kWh}$ for the manufacturing of a battery pack with an energy density of $163 \mathrm{kWh} / \mathrm{kg}$ [14]. Other studies report energy demands varying in the range of $\sim 95 \mathrm{kWh}$ to $200 \mathrm{kWh}$ per $\mathrm{kWh}$ energy content [13,52]. Schünemann et al. [52] followed a top down approach and estimated a total energy demand of $31.67 \mathrm{kWh}$ per $\mathrm{kWh}$ capacity for the manufacturing of the battery cells. Finally, Yuan et al. [53] presented detailed insights regarding energy demand, process times and material throughput in an industrial manufacturing facility for LIB cells and reported a total energy demand of $50.17 \mathrm{kWh} / \mathrm{kg}_{\text {battery }} 38 \%$ of which is demanded during the electrode drying and $43 \%$ by the dry room. Regarding the difference on the cell material, the study by Kim and colleagues analyzed the production of $24 \mathrm{kWh}$ traction battery in a cooperation with Ford and LG Chem [12]. The battery consists of LMO- and NMC-based LIB cells, but, as they argued, they did not find any significant difference in the energy demand for the production of the cells with different materials. While some studies have used primary data from companies, some questions regarding factory capacity and allocation of the energy demanded by the factories technical building services (TBS) are still open $[12,14]$. The reviewed LCA studies use EV traction LIB with pack weights of $210-300 \mathrm{~kg}$, which accounts for $20-30 \%$ of the total EV weight. Disregarding the reported energy density of the battery system, this ratio of active to inactive material at a battery pack level was found to be comparable within the different studies available from literature. Ellingsen et al. [14] mainly built their life cycle inventory based on a bill of materials of a company manufacturing traction 
batteries. They reported a share of $60 \%$ of active materials for a battery pack with an energy density of around $105 \mathrm{Wh} / \mathrm{kg}$. Diekmann and colleagues report a generic composition of a traction battery pack and in their study the share of active material to be 55\% [54]. This same share is reported by Kim and colleagues whose battery pack had an energy density of around $80 \mathrm{Wh} / \mathrm{kg}$ [12]. Deng and colleagues modeled a LSB battery pack with an energy capacity of $220 \mathrm{Wh} / \mathrm{kg}$ and calculated a share of active material of $65.9 \%$ [47]. However, in their study they did not set any volume constraint for the active material. Finally, the battery modeled by Yuan and colleagues consisted on a $66 \%$ of active material [53]. Both, the studies from Deng and Yuan made used of the BatPac tool to configure their battery packs [55].

\section{Goal and Scope}

The goal of this study is to describe and compare the environmental impacts of an LIB system against a lithium-sulfur battery (LSB) for mobile applications (EV and electric aircraft). The analyzed LIB system is an energy-optimized NMC111 with a graphitic anode, whereas the LSB is composed of a sulfur cathode and lithium-metal as anode. The boundaries of the analyzed product systems are shown in Figure 1. In this study, we considered the whole life cycle of both battery systems. This includes the production of the materials required for the cell manufacturing and the peripheral components such as modules and pack housing, cooling system and battery management system (BMS). The production of the slurries was considered according to process data obtained from the Battery LabFactory Braunschweig (BLB), a pilot scale production facility for the research and development of battery cells. Electrode manufacturing and assembly of cells and the battery pack, particularly the energy demanded in these processes, has been modeled mostly based on literature data. Data from battery systems disassembled within the context of the LithoRec project were used to model the peripheral elements of the battery pack [54,56-61]. The total battery cell volume of the disassembled battery system was estimated and set as a constraint to model the evaluated systems in this study. In order to ensure the comparability of both systems, we have configured a battery system for one specific application using each of the technologies. Particularly, we have configured two battery packs to be able to power the same mid-size EV to which the disassembled battery pack actually belongs. As a starting point for the discussion, it was assumed that the production of the cells, the assembly of the battery and the use phase takes place in Europe. The use phase and the recycling of the battery system has also been included in the study. We have estimated the impact caused per $\mathrm{km}$ in each of the cases considering the particular effect of weight to the overall energy consumption of the EV. In this study, the results are presented for different functional units in order to be able to compare our results against the available literature. These are presented per unit (i.e., per pack), per kg of battery and per storage capacity.

A sensitivity analysis for three parameters is included in this study. We evaluated the effect of reducing the amount of the solvent $N$-Methyl-2-pyrrolidone (NMP) in the dispersion process of the sulfur cathode. The thickness of the metallic lithium foil was evaluated in a sensitivity analysis for LSB cells. Furthermore, the effect of regional electricity mixes used for the production of cells was investigated. The background database used was Ecoinvent 3.3 [62] and ReCiPe [63] for midpoint indicators was applied as the impact assessment method. In this study, a total of 13 impact categories where investigated: global warming potential (GWP) in $\mathrm{kg} \mathrm{CO}_{2}$-eq, fossil depletion potential (FDP) in kg oil-eq, ozone depletion potential (ODP) in kg CFC-11-eq, photo oxidation formation potential (POFP) in kg NMVOC, particulate matter formation potential (PMFP) in kg PM10-eq, terrestrial acidification potential (TAP) in $\mathrm{kg} \mathrm{SO}_{2}$-eq, freshwater eutrophication potential (FEP) in $\mathrm{kg}$ P-eq, marine eutrophication potential (MEP) in $\mathrm{kg} \mathrm{N}$-eq, freshwater toxicity potential (FETP) in $\mathrm{kg}$ 1.4-DCB-eq, marine toxicity potential (METP) in $\mathrm{kg}$ 1.4-DCB-eq, terrestrial eutrophication potential (TETP) in $\mathrm{kg}$ 1.4 DCB-eq, human toxicity potential (HTP) in kg 1.4-DCB-eq and metal depletion potential (MDP) in $\mathrm{kg}$ N-eq. 


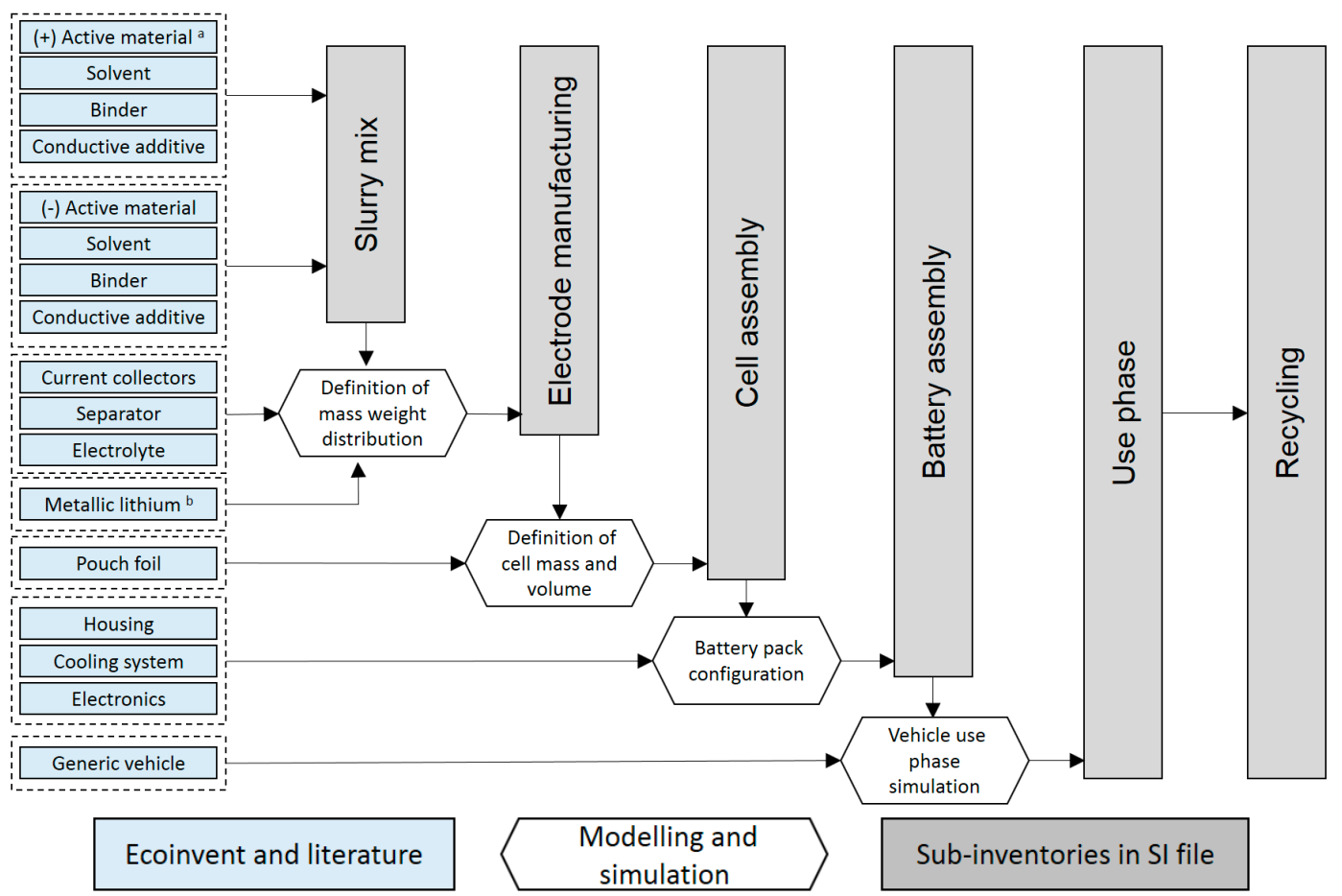

Figure 1. Description of the methodology followed and boundaries of the product systems. a The production of NMC was modeled based on the inventories provided in $[13,14]$; ${ }^{b}$ metallic lithium only for the LSB. Ecoinvent is a commercial provider of datasets for the environmental assessment of products. SI refers to supplementary information.

\section{Life Cycle Inventory Analysis}

\subsection{Energy Density, Mass and Mass Distribution at Stack, Cell and Pack Level}

Figure 1 shows the steps followed to build the life cycle inventory required for the study. The specific inputs and outputs for each of the considered processes can be consulted in the supplementary information. The first step was to determine the distribution of weight at stack level for each of the systems. For this purpose, several assumptions were made. For the calculation of the LIB cell, we used an NMC111-based cathode and a graphite-based anode. For the LSB cell, we used a sulfur cathode containing carbon-black as conductive additive and polyvinylidene difluoride (PVDF) as binder together with a lithium metal counter electrode. Material and energy inventories required for the production is reported in the supplementary information. The inventory used for the production of the LIB cathode, namely NMC111, has been taken from previous research approaches containing a comprehensive description of the manufacturing process [13,14]. Table 2 lists the main characteristics of the materials used for the calculation. Due to the pronounced electrolyte consumption of LSBs during operation we assumed a ratio of electrolyte to sulfur of approximately $6 \mathrm{~mL} / \mathrm{g}_{\text {sulfur }}[23,25]$. Additional volume and mass of the material class "Separator + electrolyte" considers the needed excess electrolyte, which leads to an increase of energy density and specific energy. 
Table 2. Material characteristics used for the calculation of the specific energy and energy density of the battery stacks.

\begin{tabular}{cccc}
\hline \multicolumn{4}{c}{ Material Characteristics } \\
\hline Active Material (AM) & Discharge Capacity $(\mathbf{m A h} / \mathbf{g})$ & Bulk Density $\mathbf{( g / \mathbf { c m } ^ { 3 } )}$ & $\begin{array}{c}\text { Average Discharge } \\
\text { Potential (V) }\end{array}$ \\
\hline NMC111 & 154 & 4.70 & 3.70 \\
Graphite (Gr) & 372 & 2.20 & 0.10 \\
Sulfur (S8) & 1672 & 2.07 & 2.10 \\
Lithium metal & 3884 & 0.53 & 0.00 \\
& & & vs. Li/Li+ \\
\hline Inactive Materials & Thickness $(\boldsymbol{\mu m})$ & Density $\left(\mathbf{g} / \mathbf{c m}^{\mathbf{3}}\right)$ & Specific Mass $\left(\mathbf{m g} / \mathbf{c m}^{\mathbf{2}}\right)$ \\
\hline Binder & - & 1.80 & - \\
Pos. current collector & 10 & 2.70 & 2.70 \\
Neg. current collector & 5 & 8.96 & 4.48 \\
Separator + electrolyte & 20 & 1.05 & 2.10 \\
Conductive additive (C65) & - & 2.25 & - \\
\hline
\end{tabular}

The electrode properties were determined experimentally at the BLB. The electrodes were manufactured following a batch-dispersing process in a planetary mixer for LIB (PMH-10, Netzsch-Feinmahltechnik GmbH, Selb, Germany) and a continuous dispersing process in an extruder (ZSK 18 MEGAlab, Coperion GmbH, Stuttgart, Germany) for LSB. It is important to mention that the amount of NMP required for the slurry production was measured to be approximately $820 \mathrm{~g}$ per $\mathrm{kg}$ of NMC-electrode solids mixture and $4 \mathrm{~kg}$ per $\mathrm{kg}$ of sulfur-electrode solids for the LSB. Due to the high amount of carbon black within the sulfur cathode (see Table 3), only a low solid sulfur solids content of $20 \%$ can be used in order to achieve a processable slurry viscosity. In the next step, the electrodes were coated on a continuous coating machine (LabCo, Kroenert GmbH, Hamburg, Germany). The produced electrodes were calendared (GKL 400, Saueressig GmbH, Vreden, Germany) to the coating densities shown in Table 2. The material inventory of the electrode manufacturing process has been included in the supplementary information file in Tables S4.1-S4.3 and S5.1-S5.4.

Table 3. Electrode composition and properties use for the calculations (own data from experimental results).

\begin{tabular}{|c|c|c|c|c|c|c|c|c|c|}
\hline \multicolumn{10}{|c|}{ Electrode Composition and Properties } \\
\hline Electrode & $\mathbf{A M}$ & (wt.\%) & CA & (wt.\%) & Binder & (wt.\%) & Porosity (\%) & Density $\left(\mathrm{g} / \mathrm{cm}^{3}\right)$ & $\begin{array}{c}\text { Density Incl. } \\
\text { Electrolyte }\left(\mathrm{g} / \mathrm{cm}^{3}\right)\end{array}$ \\
\hline LIB-Cathode & NMC111 & $96 \%$ & C65 & $2 \%$ & 5130 & $2 \%$ & $37 \%$ & 2.82 & 3.21 \\
\hline LIB-Anode & SMGA4 & $92 \%$ & C65 & $3 \%$ & $\mathrm{CMC} / \mathrm{SBR}$ & $5 \%$ & $32 \%$ & 1.51 & 1.85 \\
\hline LSB-Cathode & $\mathrm{S}_{8}$ & $60 \%$ & C65 & $30 \%$ & 5130 & $10 \%$ & $60 \%$ & 0.72 & 1.35 \\
\hline LSB-Anode & Li-metal & $100 \%$ & - & - & - & - & $0 \%$ & 0.53 & 0.53 \\
\hline \multicolumn{10}{|c|}{$C A=$ conductive additive } \\
\hline
\end{tabular}

From the results in Tables 2 and 3, we estimated the areal mass loading, thickness and areal capacity at stack level for each battery technology. The results are shown in Table 4 . For the lithium metal foil, we have used the thinnest lithium foil available on the market disregarding costs. As seen, the area capacity of lithium metal is approximately two times higher than that of the sulfur cathode. Reducing this excess is currently an important goal in current research. 
Table 4. Parameters of the full cells at stack level, which are assembled from the manufactured electrodes and are further, calculated for the LSB system (own data from experimental results).

\begin{tabular}{cccccccc}
\hline \multicolumn{9}{c}{ Cell stacks Assembly } \\
\hline \multicolumn{1}{c}{ Cell } & $\begin{array}{c}\text { Nominal Cell } \\
\text { Voltage }(\mathrm{V})\end{array}$ & $\begin{array}{c}\text { Thickness } \\
(\boldsymbol{\mu})\end{array}$ & $\begin{array}{c}\text { Areal Mass } \\
\left(\mathbf{m g} / \mathbf{c m}^{2}\right)\end{array}$ & $\begin{array}{c}\text { Area Capacity } \\
\left(\mathbf{m A h} / \mathbf{c m}^{2}\right)\end{array}$ & $\begin{array}{c}\text { Thickness } \\
(\boldsymbol{\mu m})\end{array}$ & $\begin{array}{c}\text { Area Mass } \\
\left(\mathbf{m g} / \mathbf{c m}^{2}\right)\end{array}$ & $\begin{array}{c}\text { Area Capacity } \\
\left(\mathbf{m A h} / \mathbf{c m}^{2}\right)\end{array}$ \\
\hline NMC//Gr & 3.7 & 55.7 & 15.70 & 2.32 & 53.8 & 7.33 & 2.51 \\
S8//Li & 2.1 & 63.6 & 4.87 & 5.33 & 50.0 & 2.46 & 9.54 \\
\hline
\end{tabular}

With the measured electrode thicknesses, the resulting specific energies and energy densities of the manufactured LIB and LSB cells were estimated. To compare the LSB system on a stack level against the LIB system, a few assumptions had to be made. The thickness of the lithium foil was assumed with $50 \mu \mathrm{m}$. The lever of this assumption will be investigated in a sensitivity analysis. An identical separator thickness of $20 \mu \mathrm{m}$ was assumed for both systems. The amount of electrolyte required was aggregated and reported as a combined density of separator and electrolyte as shown in Table 2. The electrolyte is stored within the void volume of anode and cathode, the separator, as well as the separator around the stack. Additionally, the void volume of the pouch housing has been also considered in the calculation. Because of the early stage of development, a protective layer on the lithium metal is not considered for this calculation. These calculations lead to the stack level energy in Table 5. As shown, the LSB system offers a specific energy of around $80 \%$ higher than the LIB and with about $23 \%$ increased volumetric energy density.

Table 5. Thickness and area mass (including anode, separator, cathode and electrolyte) on stack level for LIB and LSB as well as following calculated specific energy and the energy density.

\begin{tabular}{ccccc}
\hline \multicolumn{5}{c}{ Total Stack Level } \\
\hline Cell & Thickness $(\boldsymbol{\mu m})$ & Area Mass $\left(\mathbf{m g} / \mathbf{c m}^{2}\right)$ & Energy Density $(\mathbf{W h} / \mathrm{L})$ & Specific Energy $(\mathbf{W h} / \mathbf{k g})$ \\
\hline NMC//Gr & 148 & 37.5 & 594 & 229 \\
S8//Li & 293 & 36.9 & 382 & 303 \\
\hline
\end{tabular}

In order to estimate the mass and volume of a battery cell, we assumed a specific geometry based on current cell formats available at the BLB. The cell manufactured is composed of stacked electrodes as described in Figure S1. The material inventory of the cell produced for each of the battery systems is reported in Tables S4.1-S4.3 and S5.1-S5.4. Moving forward to the configuration of the battery pack, information regarding inactive mass and components of the traction battery was directly collected from disassembling and measuring several battery packs within the context of the project LithoRec [54,56-61]. From the disassembly experiments, it was found that for a battery pack with an energy density of around $76.4 \mathrm{kWh} / \mathrm{kg}$, the share of battery cells ranges from $60 \%$ to $65 \%$. The inactive mass share was found to be composed of $\sim 33 \%$ housing and structural elements mainly of steel, plastics and aluminum and $\sim 4 \%$ of electronics and cables. A more detailed description of the material inventory for the assembly of the assumed battery pack can be found in Table S1. Based on the disassembled battery system and the geometric information of the cell described in the section 1 of the supplementary information we estimated an available cell volume of 87 liters. This volume was set as a restriction to configure the battery systems to be compared in our study. Results regarding specific energy for the systems modeled at cell and battery pack level are shown in Figure 2. 

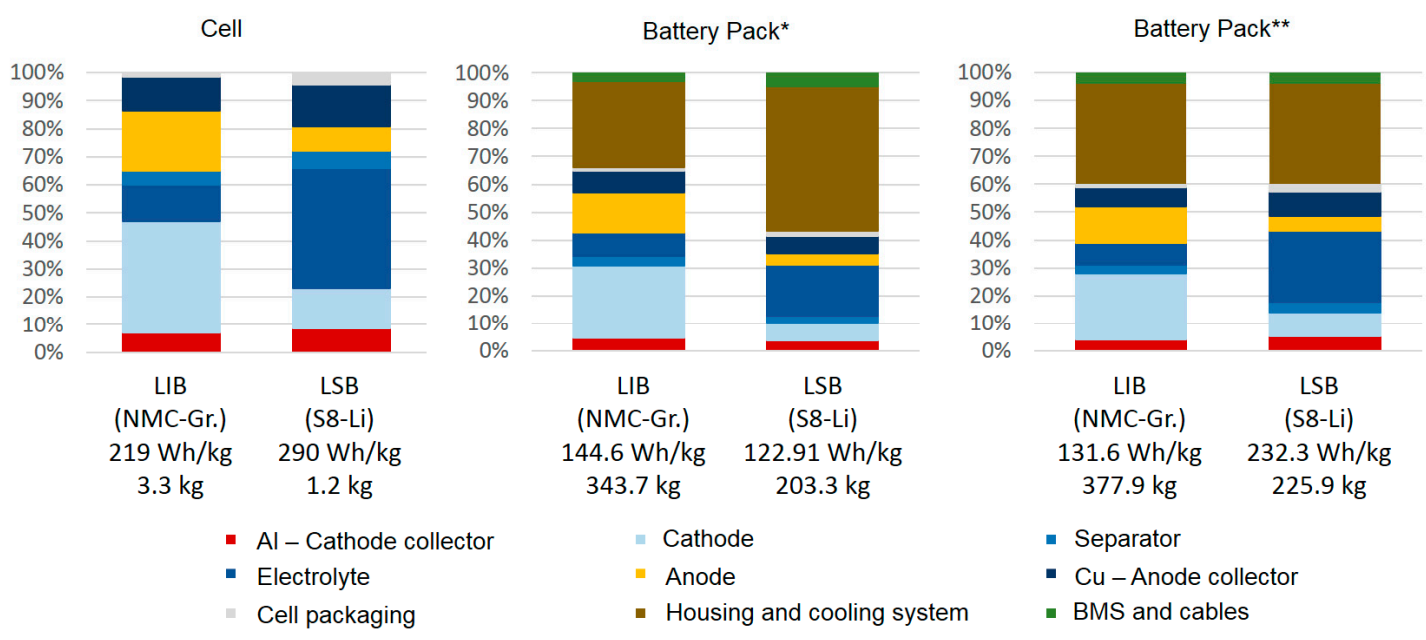

Figure 2. Mass distribution and specific energies of the main battery components at stack, cell and battery pack level. * Inactive mass is conserved as in the disassembled battery pack; ${ }^{* *}$ Inactive mass is adjusted to $40 \%$ of the whole battery pack mass.

In this regard, we modeled two different scenarios: (i) the battery packs conserve the original inactive mass as measured from the disassembly experiments. As the volume remains constant, we obtained a variation on the specific weight of each pack; (ii) the ratio between active and inactive material weight is adjusted. This scenario implies changes in the architecture of the pack or material changes of the peripheral materials and components. This adjustment resulted in an approximate $10 \%$ mass increase in the case of the LIB and a 10\% mass reduction for the LSB battery.

\subsection{Cell Manufacturing and Battery Assembly}

The energy required for the manufacturing of the battery cells was estimated based on the work from Yuan and colleagues [53]. For this study, we estimated an approximate energy demand of $4320 \mathrm{kWh}$ ( $\sim 86 \mathrm{kWh}$ per $\mathrm{kWh}$ of battery capacity or $\sim 13 \mathrm{kWh}$ per $\mathrm{kg}$ of battery) for the production of the LIB battery cells and $3610 \mathrm{kWh}$ for the LSB cells $(\sim 73 \mathrm{kWh}$ per kWh of battery energy content or $14 \mathrm{kWh}$ per kg battery). The difference between both systems lies on the fact that, contrary to the LIB, the anode in the LSB system (i.e., lithium metal) does not need to go through any dispersion, coating or calendaring process and the energy consumption of these processes depend strongly on the material throughput. While our estimations regarding energy consumption are slightly lower than currently reported values in the literature, our battery systems present a higher energy density per amount of material. This issue will be discussed further in this paper concerning LSB batteries. The material inventory built for the cell assembly phase and the battery assembly can be found in Tables S2.1-S2.5 and S3.1-S3.9. For the assembly of the battery pack we based our estimation on the assumption done by Ellingsen et al. [14] and obtained a final value of $0.2 \mathrm{kWh}$ per battery pack.

\subsection{Use Phase}

To model the use phase, a generic dataset of an EV without a battery system was used [64]. This dataset was adjusted to meet similar characteristics as the vehicle to which the disassembled battery system belongs. The analysis was restricted to the traction energy. This means energy demand due to heating, ventilation and air conditioning (HVAC) systems and other auxiliaries was not considered, assuming that the systems would not incur in different energy demands for different battery systems. The energy demand during the use phase was estimated following the simulative approach described by Bauer and colleagues [43] and by Hofer [42]. These approaches allow estimation of the energy demand per kilometer of the vehicle considering specific vehicle properties such as weight, frontal area, glider mass and components mass. This enables to estimate 
the difference in energy demanded per kilometer related to a particular change in the weight of the components. The electricity consumption has been estimated for the Worldwide Harmonized Light Vehicles Test Procedures (WLTP) average driving cycle and for the same vehicle with different battery systems. The difference due to the different weights of the batteries was found to be comparably low. For the LIB pack a consumption of $184.79 \mathrm{Wh} / \mathrm{km}$ was calculated whereas for the LSB pack the energy consumption was estimated to be $174.79 \mathrm{Wh} / \mathrm{km}$.

\subsection{Recycling and End-of-Life}

Although the recycling phase was considered, we limited the study to estimate the environmental efforts of recycling. We did not calculate possible environmental credits that might arise from the different avoided burdens implied by the recovery of metals such as metallic lithium. Since we are dealing with an emerging technology, as it is the case of the LSB, we could hardly model a recycling process that allows retrieval of valuable materials from a spent LSB battery. Thus, we restricted this part of the study that evaluates the impacts rising from the efforts of separating a battery system and treating its parts. The data used for this part of the study has been taken from the LithoRec project, which is mostly composed of real measured data. Within LithoRec [56-61], it was obtained that $59 \mathrm{kWh}$ of electricity are required to treat a $350 \mathrm{~kg}$ traction battery system.

\section{Results and Discussion}

Cradle-to-gate environmental impacts for the two analyzed battery systems are summarized in in Table 6. The compositions of the impacts in terms of their main contributors are shown in Figure 3. The results are reported for three different functional units in order to allow comparison of our results to other previous studies. The amount of carbon equivalent emissions generated by the production of both systems was found to be very similar. A total amount of 5.47 tons $\mathrm{CO}_{2}$-eq $\left(16 \mathrm{~kg} \mathrm{CO}_{2}\right.$-eq per battery mass and $110 \mathrm{~kg} \mathrm{CO}$-eq per $\mathrm{kWh}$ of battery capacity) and 3.03 tons $\mathrm{CO}_{2}$-eq $\left(20 \mathrm{~kg} \mathrm{CO}_{2}\right.$-eq per battery mass and $117 \mathrm{~kg} \mathrm{CO}$-eq per $\mathrm{kWh}$ of battery capacity) were estimated for the LIB and LSB, respectively. The results are within the range of the reported results in the literature as shown in Table 1. For example, Kim and colleagues [12] reported a total of $140 \mathrm{~kg} \mathrm{CO}_{2}$-eq per $\mathrm{kWh}$ of battery for a battery system with an energy density of around $78 \mathrm{kWh} / \mathrm{kg}$. For the LIB case, approximately $30 \%$ of the GWP impact was identified as generated during the production of the cathode active material.

Table 6. Total environmental impact of the production of a LIB and a LSB battery.

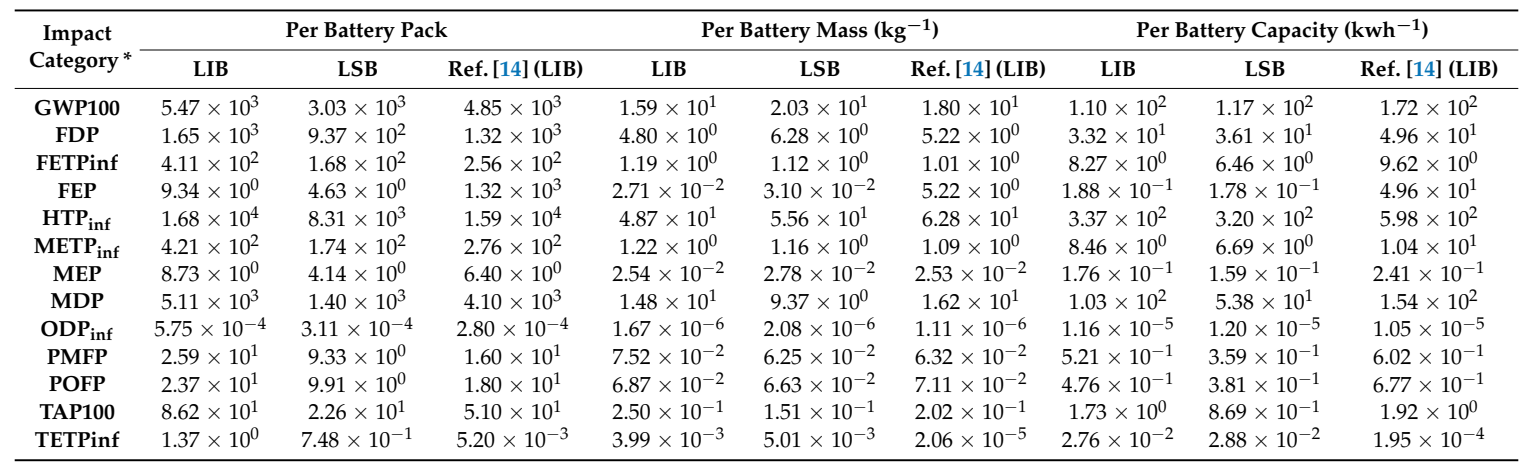

* Impact categories as characterized in the ReCiPe method: global warming potential (GWP) in $\mathrm{kg} \mathrm{CO}_{2}$-eq, fossil depletion potential (FDP) in $\mathrm{kg}$ oil-eq, ozone depletion potential (ODP) in kg CFC-11-eq, photo oxidation formation potential (POFP) in $\mathrm{kg}$ NMVOC, particulate matter formation potential (PMFP) in kg PM10-eq, terrestrial acidification potential (TAP) in $\mathrm{kg} \mathrm{SO}_{2}$-eq, freshwater eutrophication potential (FEP) in $\mathrm{kg}$ P-eq, marine eutrophication potential (MEP) in $\mathrm{kg} \mathrm{N}$-eq, freshwater toxicity potential (FETP) in $\mathrm{kg}$ 1.4-DCB-eq, marine toxicity potential (METP) in kg 1.4-DCB-eq, terrestrial eutrophication potential (TETP) in kg 1.4 DCB-eq, human toxicity potential (HTP) in $\mathrm{kg}$ 1.4-DCB-eq and metal depletion potential (MDP) in $\mathrm{kg}$ N-eq. 

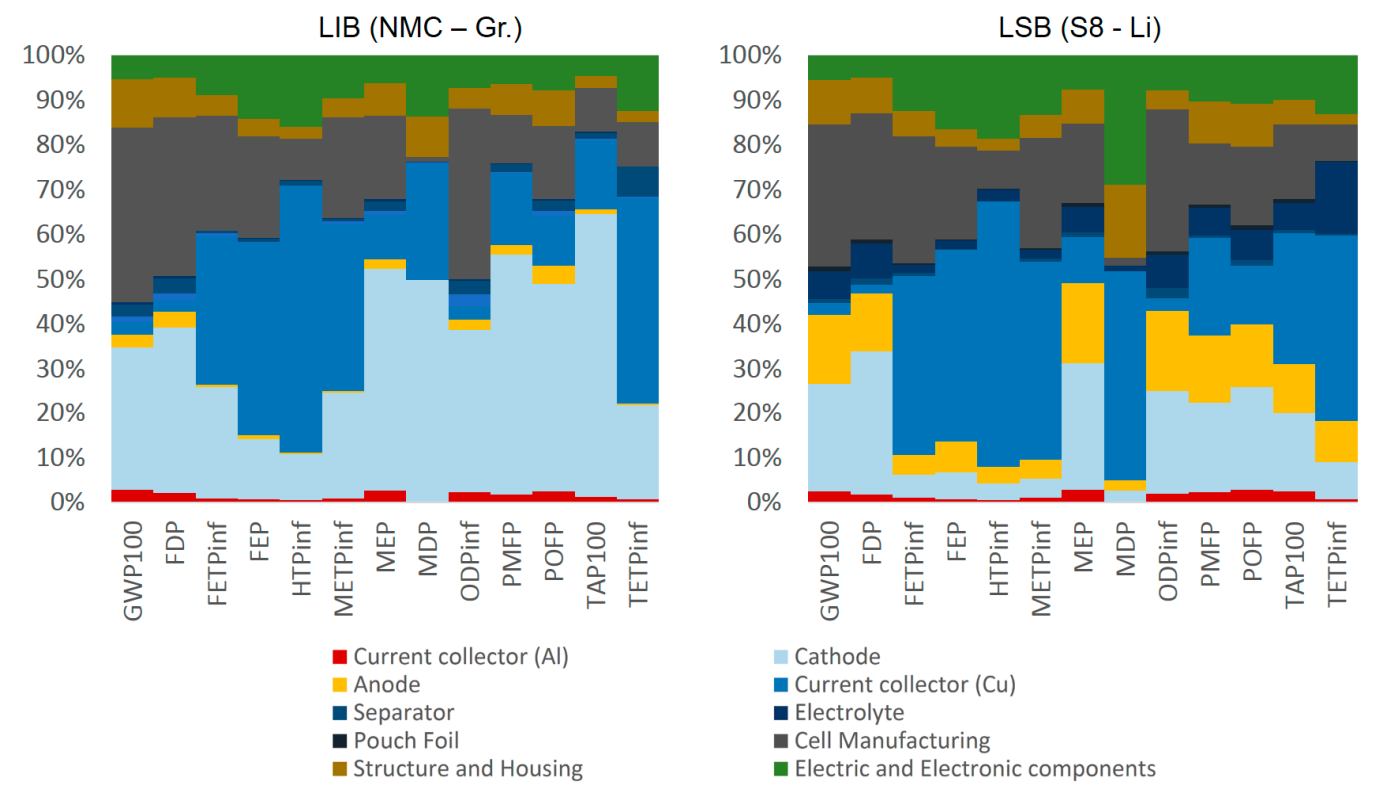

Figure 3. Contribution analysis of the environmental impacts for the production of one battery pack. Impact categories as characterized in the ReCiPe method: global warming potential (GWP) in $\mathrm{kg}$ $\mathrm{CO}_{2}$-eq, fossil depletion potential (FDP) in kg oil-eq, ozone depletion potential (ODP) in kg CFC-11-eq, photo oxidation formation potential (POFP) in $\mathrm{kg}$ NMVOC, particulate matter formation potential (PMFP) in kg PM10-eq, terrestrial acidification potential (TAP) in $\mathrm{kg} \mathrm{SO}_{2}$-eq, freshwater eutrophication potential (FEP) in kg P-eq, marine eutrophication potential (MEP) in $\mathrm{kg} \mathrm{N}$-eq, freshwater toxicity potential (FETP) in kg 1,4-DCB-eq, marine toxicity potential (METP) in $\mathrm{kg}$ 1,4-DCB-eq, terrestrial eutrophication potential (TETP) in kg 1,4 DCB-eq, human toxicity potential (HTP) in kg 1,4-DCB-eq and metal depletion potential (MDP) in $\mathrm{kg} \mathrm{N}$-eq.

Especially the production of NMP solvent has been identified to contribute $90 \%$ to the total GWP impact generated during the production of $1 \mathrm{~kg}$ of sulfur slurry and $70 \%$ of the GWP for the production of $1 \mathrm{~kg}$ of NMC slurry. Regarding other impact categories, evident advantages for the LSB can be found in toxicity related categories. For instance, the LSB presents a reduction of around $22 \%$ of marine toxicity potential METP, fresh water toxicity potential FETP and human toxicity potential HTP. For the LIB, sulfidic tailing from mining and production activities of nickel and cobalt sulfate mainly drives these categories, which are not a part of the LSB batteries. The production of the nickel sulfate is responsible for approx. 70\% of the emissions causing PMFP per kilogram of active cathode material. PMFP was found in the LSB to be reduced on a 33\% respecting the LIB. The LSB shows a significant advantage compared to the LIB pack in metal depletion potential (MDP). Around half of the total MDP impact in the LIB is driven by the cathode production. The MDP impact for the production of NMC is driven by the production of the manganese sulfate required for the synthesis of the cathode active material (70\%). The largest difference found in the Life Cycle Impact Assessment (LCIA) results is in terms of terrestrial acidification potential mainly driven by sulfur dioxide emissions generated in the production process of nickel sulfate. Consistent to the current state of research, to the most important impact sources of a battery pack, the copper used as current collector in the cell was identified to force most of the toxicity related to impacts such as METP, HTP and FETP. Additionally, the sulfidic tailings and waste from mining and production processes of copper have a potent eutrophication effect in freshwater sources.

The energy consumption within the manufacturing stage of the battery cells has been found to be responsible of $\sim 40 \%$ of the total GWP impact for the LIB and of approx. $30 \%$ for the LSB. This is consistent with the data reported in the literature as reviewed in Section 3.2. A sensitivity analysis was performed to evaluate the relevance of some of the assumptions to build the life cycle inventory for 
this study. In Figure 4 we plotted a curve describing the total amount of carbon emissions equivalent generated by the production of the two battery systems on a kilometer basis. In the figure, we show the number of kilometers achieved by both of the battery systems after the battery has completed 500 cycles. The difference in the number of cycles is directly related to the energy content of the battery pack that has been calculated for the vehicle assumed. The low volumetric energy density of the LSB limits, as seen in Figure 4, its lifespan for mobility applications such as EV. Due to its conversion-based kinetics, the life span of LSB cells (approximately 500 cycles) is one of the main challenges to get the technology ready for the market. The effect of reducing the quantity of NMP processing solvent for the preparation process of the slurry is described. The amount of NMP was calculated to be $4 \mathrm{~kg}$ per $\mathrm{kg}$ of prepared slurry (Table S5.2). The amount of NMP was reduced by a $20 \%$ and by $40 \%$ from the initial value. Only small changes in the resulting values ranging between $\sim 45$ and $50 \mathrm{~g} \mathrm{CO}_{2}$-eq per $\mathrm{km}$ for a driven distance of $60,000 \mathrm{~km}$ were found. A second analysis was done to evaluate the influence of the geographical location of the manufacturing facility. As mentioned, the energy demand during the manufacturing phase of the cell can produce up to $50 \%$ of the total GWP related emissions. This has been found to be a critical parameter. Changes in locations result in increased impact ranging from $20 \%$ to $45 \%$.

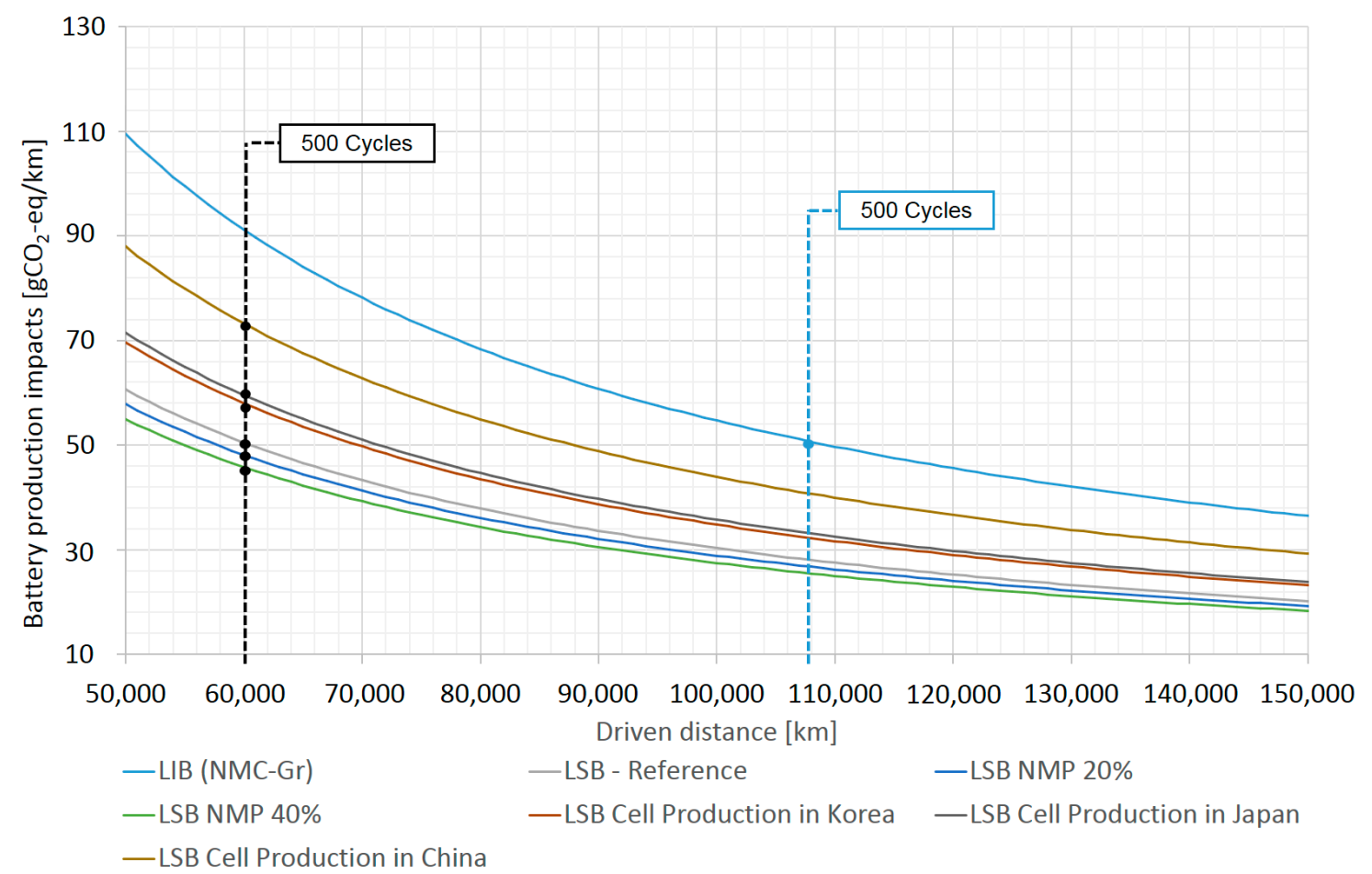

Figure 4. Sensitivity analysis 1. Effect of reduced amount of solvent for the production sulfur (S8) slurry to the total GWP of a battery pack through its lifecycle in $\mathrm{g} \mathrm{CO}_{2}$-eq per $\mathrm{km}$. Effect of regional different geographical production locations to the total GWP of a battery through its lifecycle.

The use of a metallic lithium foil as the anode for the LSB battery was estimated to contribute to approximately a $15 \%$ of the total GWP emissions of the battery as seen in Figure 3. Lithium mining activities are associated with a lower energy demand and reduced emissions compared to the mining of $\mathrm{Ni}$ or $\mathrm{Co}$ [7]. Li metal is manufactured through salt electrolysis of lithium chloride. Embodied energy for primary production of lithium ranges between $495 \mathrm{MJ}$ and $546 \mathrm{MJ}$ per $\mathrm{kg} \mathrm{Li}$ with a commercial purity of $99 \%$ [65]. This component was found to have a relevant contribution to other impact categories, related to emissions produced for the supply of energy such as fossil depletion potential FDP and particulate matter formation PMFP. The two most important issues around the model of the lithium foil for the purpose of this paper, were first to identify the energy required for the manufacturing process 
and second to evaluate the effect of increasing and decreasing its thickness in the cell. Regarding the manufacturing energy, we varied the energy reported for the production of the lithium foil between the maximum and the minimum value. The energy required by a foil rolling process for lithium has been reported to vary between $0.62 \mathrm{MJ}$ and $0.68 \mathrm{MJ}$ per $\mathrm{kg}$ of foil rolled [65]. No significant difference was found between the environmental impacts resulting from both scenarios (this result is not shown in the figures).

Regarding the thickness of the lithium foil, we varied it from $29 \mu \mathrm{m}$ to a maximum of $100 \mu \mathrm{m}$. No significant changes to the environmental impact of the battery system were identified after varying these parameters. However, this reduction of $21 \mu \mathrm{m}$ causes an increase in the energy density at cell level leading subsequently to an increase of the potential driven distance of approximately $6000 \mathrm{~km}$ for a reference of 500 cycles. In the same way, increasing the Li foil thickness leads to reaching 500 cycles approx. 10,000 km earlier for the given use phase configuration.

\section{Main Findings and Implications}

In this paper, we aimed at analyzing the influence of increasing energy the density to the environmental impacts of traction batteries. In our study, we investigated a LSB battery and benchmarked the results against the environmental impacts of a standard LIB (NMC111/graphite) battery system. This study has a prospective character as LSB batteries are still under development. Nevertheless, the battery cells were manufactured and characterized in a pilot scale facility using industrial standards. While from the results it cannot be stated categorically whether a LSB battery system outperforms the LIB battery, we identified the aspects to which the impact of LSB depends. Following we provide insights of possible strategies to support its development and implementation.

\subsection{Use of Water-Base Solvents}

The use of NMP during the production of the sulfur cathode slurry, together with the amount of energy demanded in the manufacturing phase, has the largest environmental impact. As seen in Table S5.2, NMP represented up to $80 \mathrm{wt}$. \% of the slurry mix for the LSB system. This issue faces several environmental challenges. On the one side, NMP it can be absorbed by the skin or inhaled causing serious health issues [66]. On the other side, not only the production of NMP is responsible of a large amount of GHG emissions on a kilogram basis, but also the preparation of the sulfur cathode demanded a huge amount of this processing solvent. According to Wood and colleagues [67] more energy is required to remove NMP during the drying process of the electrode than for other solvents such as water, due to the low vapor pressure of NMP. Zackrisson et al. [49] also evaluated the use of water-based solvents for the production of a NMC cathode, however their results are based on a hypothetical cell and the performance of the cell was not considered in the study. Another alternative is the recovery of NMP after the drying process. This strategy has been described as being expensive due to the infrastructure required and additional safety standards to which the equipment is required to be compliant with [67]. A further alternative is the development of solvent-free manufacturing processes for battery electrodes as described by Ludwig and colleagues [68] for the case of a lithium cobalt oxide-based (LCO) battery and by Thieme et al. for the case of LSB batteries [69].

\subsection{Thickness of the Lithium Foil and Alternative Anodes}

The use of metal lithium as the anode in the LSB battery was found to have a significant influence to both the energy density of the cell and the environmental impact of the battery system. The use of a thinner foil implies on the one side the requirement of larger amounts of other active materials. This causes an increase in impact categories such as GWP or ADP do to the additional amount of solvent required. However, this increase in energy density contributed to increase the number of kilometers available to be driven for a specific amount of battery cycles. This has therefore a positive repercussion on the environmental impact of the LSB battery system on a kilometer basis. Compared to 
the lithium anode, lithiated graphite anodes may offer important advantages regarding safety and cost issues $[70,71]$, but it also might contribute to reducing the environmental impact of LSB.

\subsection{Limitations and Future Work}

This is a study limited to analyze the environmental impact of LSB batteries for mobility applications. Although this study followed an extensive procedure, the approach followed is based on several assumptions and future work is necessary to understand the environmental implications LSB batteries. Following we summarized the necessary future research to enhance the understanding regarding the environmental impacts of LSB batteries.

\subsection{More Detailed Research on the Effect of Lithium Metal}

While many of the environmental impacts from the production of lithium are already considered within the commercial databases such as Ecoinvent, the criticality issues of lithium are still not included in the ReCiPe methodology [72] and therefore its depletion potential are not reflected within the MDP results. This is important as the LSB battery analyzed contains much more lithium as the LIB. The amount of lithium in a LIB-based battery pack amounts to roughly a 1\% [54], while for a LSB battery this amount increases to approximately a $10 \%$ on cell level as estimated in this paper. As seen in Table 6, MDP results for LSB are around 40\% lower than the LIB. While the availability of lithium in the world to supply the mobility industry has been many times found to be sufficient [6], such analysis has been done for state of the art LIBs.

\subsection{Manufacturing Energy for LSB}

In order to improve the understanding of environmental impacts of LSB batteries, a more detailed energy analysis needs to be done. Our estimation of energy demanded $(80 \mathrm{kWh} / \mathrm{kWh}$ battery for the LIB and $\sim 72 \mathrm{kWh} / \mathrm{kWh}$ battery for the LSB) during this phase for the LSB cells are aligned to most of the bottom-up approaches in the literature $[12,13,25,53]$ in the literature $\left(90-162 \mathrm{kWh} / \mathrm{kWh}_{\text {battery }}\right)$. Nevertheless, the energy demanded by the manufacturing processes of the LSB are based on data reported by Yuan and colleagues [53] which refers to the production of a LIB battery. The production processes of LSB cells present some differences that might result in variations of the energy demanded. Some differences regarding the manufacturing of electrodes are to be considered. On the one side, neither coating nor dispersing processes are required to produce the anode. This implies significant energy savings as the drying process has been identified to be one of the highest energy demanders [53]. On the other side, the high amounts of NMP required to produce the sulfur slurry might cause an increase in the drying time of the cathode as all the solvent must be evaporated and therefore an increased amount of energy is consumed. Another important issue to mention in this matter is the fact that lithium metal is a very sensitive metal that reacts violently with ambient humidity and body moisture. This implies that to handle this material, special infrastructure is required in the factory (e.g., dry rooms, inert glove boxes).

\subsection{Estimating the Effect of Avoided Burden Due to Recycling}

In our study, we considered only the amount of energy required the recycling process. We did not include possible avoided burdens caused by the recovery of materials. This issue should research with more detail as the differences between the two systems might cause large differences in the results of the environmental assessment of the recycling step. While the recovery of sulfur from batteries might not be as economically attractive as from the cathode active materials found in the LIB (e.g., cobalt, nickel, etc.), recovering lithium can drive the development of specific recycling processes for LSB batteries in the future. 


\subsection{Extending the Scope to Other Mobility Systems Such as Aviation}

Particularly for the case of private mobility, LSB batteries face a big challenge due to the volumetric constraint proper of the automotive industry. LSB batteries, although lighter, require much more volume. Nevertheless, that LSB energy density is further improved to meet the requirements of larger transportation vehicles such as aircrafts, it might be possible to allocate the space required by the cells and the inactive components in several parts of the vehicle leading to more energy capacity.

\section{Conclusions}

In this paper, we presented an evaluation of potential life cycle environmental impacts of LSB batteries. We benchmarked the results against the environmental impacts of a LIB battery using NMC111 as a case study. For our research, real electrodes for both LSB and LIB were manufactured and their properties were measured. To ensure comparability we configured two battery systems providing the same amount of energy for the same application, a mid-size European passenger car. The mass distribution of the two battery systems was estimated and configured based on disassembly data collected from the LithoRec project. The energy demanded within the manufacturing phase of the cells was estimated based on a top-down approach from the literature. To estimate the energy consumption during the use phase a simulative approach was followed that allowed calculating the energy demand per kilometer while considering the differences in the mass of the vehicle due to the differences of the battery packs. From our research, we did not find a large difference in the environmental impact of LSB compared to LIB. The amount of solvent required the processing of the sulfur cathode; the thickness of the lithium metallic foil and the demanded energy in the manufacturing processes were identified as the most significant drivers of environmental impacts for the LSB. A broader analysis scope could contribute to enhancing the understanding of the many dimensions in which LSB might affect the environment. In this regard, we identified possible further research on the production of metallic lithium and the comprehensibility of the commercial environmental databases and methodologies to assess it. Additionally, a more detailed analysis of manufacturing and recycling phases for LSB is recommended. Finally, the benefits of the implementation of LSB batteries in other mobility sectors such as aviation and space might become profitable as a smaller volumetric constraint might allow a more flexible use of the space for the active material and additionally an advantage over the specific energy of LIBs.

Supplementary Materials: The following are available online at www.mdpi.com/1996-1073/11/1/150/s1. Life Cycle Inventories for both the LIB and LSB batteries.

Acknowledgments: The authors wish to thank the German Ministry of Education and Research (BMBF) for funding this work in the project "BenchBatt" (03XP0047C).

Author Contributions: The experimental manufacturing of the LIB and LSB electrodes was carried out by Paul Titscher. The estimation of the electrochemical properties of the LIB and LSB batteries was performed in collaboration among Paul Titscher, Richard Schmuch and Felipe Cerdas. The modelling of life cycle inventories, the life cycle assessment and the analysis of results were performed by Felipe Cerdas. The article was written jointly by Felipe Cerdas, Paul Titscher, Nicolas Bognar, Richard Schmuch, Martin Winter, Arno Kwade and Christoph Herrmann. This article was prepared in a joint research consortium; all authors have contributed substantially to this publication.

Conflicts of Interest: The authors declare no conflict of interest. 


\section{Abbreviations}

$\begin{array}{ll}\text { LCA } & \text { Life Cycle Assessment } \\ \text { LIB } & \text { Lithium-ion battery } \\ \text { LSB } & \text { Lithium-sulfur battery } \\ \text { NMP } & \text { N-Methyl-2-pyrrolidone } \\ \text { IEA } & \text { International Energy Agency } \\ \text { GHG } & \text { green-house gas } \\ \text { EVs } & \text { electric vehicles } \\ \text { GWP } & \text { global warming potential } \\ \text { ICEVs } & \text { internal combustion engine vehicles } \\ \text { NMC } & \text { lithium manganese cobalt oxide } \\ \text { LMO } & \text { lithium manganese oxide } \\ \text { LFP } & \text { lithium iron phosphate } \\ \text { PVDF } & \text { polyvinylidene difluoride } \\ \text { HVAC } & \text { heating, ventilation and air conditioning } \\ \text { WLTP } & \text { worldwide harmonized light vehicles test procedures }\end{array}$

\section{Nomenclature}

\begin{tabular}{|c|c|}
\hline GWP & global warming potential (kg CO2-eq) \\
\hline FDP & fossil depletion potential (kg oil-eq) \\
\hline ODP & ozone depletion potential (kg CFC-11-eq) \\
\hline POFP & photo oxidation formation potential (kg NMVOC) \\
\hline PMFP & particulate matter formation potential (kg PM10-eq) \\
\hline TAP & terrestrial acidification potential $\left(\mathrm{kg} \mathrm{SO}_{2}-\mathrm{eq}\right)$ \\
\hline FEP & freshwater eutrophication potential (kg P-eq) \\
\hline MEP & marine eutrophication potential (kg N-eq) \\
\hline FETP & freshwater toxicity potential ( $\mathrm{kg}$ 1.4-DCB-eq) \\
\hline METP & marine toxicity potential (kg 1.4-DCB-eq) \\
\hline TETP & terrestrial eutrophication potential (kg 1.4 DCB-eq) \\
\hline HTP & human toxicity potential (kg 1.4-DCB-eq) \\
\hline MDP & metal depletion potential (kg N-eq) \\
\hline
\end{tabular}

\section{Subscripts}

$\begin{array}{ll}\text { inf. } & \text { infinite } \\ 100 & 100 \text { years } \\ \text { Wt. \% } & \text { weight percent }\end{array}$

\section{References}

1. Karagulian, F.; Belis, C.A.; Dora, F.C.; Prüss-Ustün, A.M.; Bonjour, S.; Adair-Rohani, H.; Amann, M. Contributions to cities' ambient particulate matter (PM): A systematic review of local source contributions at global level. Atmos. Environ. 2015, 120, 475-483. [CrossRef]

2. International Energy Agency (IEA). $\mathrm{CO}_{2}$ Emissions from Fuel Combustion (Highlights 2015 Edition); International Energy Agency: Paris, France, 2015.

3. International Energy Agency (IEA). Global EV Outlook 2016 beyond One Million Electric Cars; International Energy Agency: Paris, France, 2016.

4. Sims, R.; Schaeffer, R.; Creutzig, F.; Cruz-Núñez, X.; D’Agosto, M.; Dimitriu, D.; Figueroa Meza, M.J.; Fulton, L.; Kobayashi, S.; Lah, O.; et al. Transport. In Climate Change 2014: Mitigation of Climate Change. Contribution of Working Group III to the Fifth Assessment Report of the Intergovernmental Panel on Climate Change; Edenhofer, O., Pichs-Madruga, R., Sokona, Y., Farahani, E., Kadner, S., Seyboth, K., Adler, A., Baum, I., Brunner, S., Eickemeier, P., et al., Eds.; Cambridge University Press: Cambridge, UK; New York, NY, USA, 2014. 
5. Hawkins, T.R.; Singh, B.; Majeau-Bettez, G.; Strømman, A.H. Comparative Environmental Life Cycle Assessment of Conventional and Electric Vehicles. J. Ind. Ecol. 2013, 17, 53-64. [CrossRef]

6. Nitta, N.; Wu, F.; Lee, J.T.; Yushin, G. Li-ion battery materials: Present and future. Mater. Today 2014, 18, 252-264. [CrossRef]

7. Dunn, J.B.; Gaines, L.; Kelly, J.C.; James, C.; Gallagher, K.G. The significance of Li-ion batteries in electric vehicle life-cycle energy and emissions and recycling's role in its reduction. Energy Environ. Sci. 2015, 8, 158-168. [CrossRef]

8. Placke, T.; Kloepsch, R.; Dühnen, S.; Winter, M. Lithium ion, lithium metal, and alternative rechargeable battery technologies: The odyssey for high energy density. J. Solid State Electrochem. 2017, 21, 1-26. [CrossRef]

9. Sun, H.H.; Choi, W.; Lee, J.K.; Oh, I.H.; Jung, H.G. Control of electrochemical properties of nickel-rich layered cathode materials for lithium ion batteries by variation of the manganese to cobalt ratio. J. Power Sources 2015, 275, 877-883. [CrossRef]

10. Hayner, C.M.; Zhao, X.; Kung, H.H. Materials for Rechargeable Lithium-Ion Batteries. Annu. Rev. Chem. Biomol. Eng. 2012, 3, 445-471. [CrossRef] [PubMed]

11. Etacheri, V.; Marom, R.; Elazari, R.; Salitra, G.; Aurbach, D. Challenges in the development of advanced Li-ion batteries: A review. Energy Environ. Sci. 2011, 4, 243. [CrossRef]

12. Kim, H.C.; Wallington, T.J.; Arsenault, R.; Bae, C.; Ahn, S.; Lee, J. Cradle-to-Gate Emissions from a Commercial Electric Vehicle Li-Ion Battery: A Comparative Analysis. Environ. Sci. Technol. 2016, 50, 7715-7722. [CrossRef] [PubMed]

13. Majeau-Bettez, G.; Hawkins, T.R.; Strømman, A.H. Life Cycle Environmental Assessment of Li-iion and Nickel Metal Hydride Batteries for Plug-in Hybrid and Battery Electric Vehicles. Supporting Information. Environ. Sci. Technol. 2011, 45, 4548-4554. [CrossRef] [PubMed]

14. Ellingsen, L.A.-W.; Majeau-Bettez, G.; Singh, B.; Srivastava, A.K.; Valøen, L.O.; Strømman, A.H. Life Cycle Assessment of a Lithium-Ion Battery Vehicle Pack. J. Ind. Ecol. 2014, 18, 113-124. [CrossRef]

15. Panchal, S.; Mathewson, S.; Fraser, R.; Culham, R.; Fowler, M. Thermal Management of Lithium-Ion Pouch Cell with Indirect Liquid Cooling using Dual Cold Plates Approach. SAE Int. J. Altern. Powertrains 2015, 4, 293-307. [CrossRef]

16. Panchal, S.; Mcgrory, J.; Kong, J.; Fraser, R.; Fowler, M.; Dincer, I.; Agelin-Chaab, M. Cycling degradation testing and analysis of a LiFePO4 battery at actual conditions. Int. J. Energy Res. 2017, 41, 2565-2575. [CrossRef]

17. Manthiram, A.; Fu, Y.; Chung, S.H.; Zu, C.; Su, Y.S. Rechargeable lithium-sulfur batteries. Chem. Rev. 2014, 114, 11751-11787. [CrossRef] [PubMed]

18. Samaniego, B.; Carla, E.; O'Neill, L.; Nestoridi, M. High specific energy Lithium Sulfur cell for space application. E3S Web Conf. 2017, 16, 8006. [CrossRef]

19. Manthiram, A.; Chung, S.-H.; Zu, C. Lithium-Sulfur Batteries: Progress and Prospects. Adv. Mater. 2015, 27, 1980-2006. [CrossRef] [PubMed]

20. Berg, E.J.; Villevieille, C.; Streich, D.; Trabesinger, S.; Novák, P. Rechargeable Batteries: Grasping for the Limits of Chemistry. J. Electrochem. Soc. 2015, 162, A2468-A2475. [CrossRef]

21. Wild, M.; O'Neill, L.; Zhang, T.; Purkayastha, R.; Minton, G.; Marinescub, M.; Offer, G.J. Lithium sulfur batteries, a mechanistic review. Energy Environ. Sci. 2015, 8, 3477-3494. [CrossRef]

22. Hagen, M.; Hanselmann, D.; Ahlbrecht, K.; Maça, R.; Gerber, D.; Tübke, J. Lithium-Sulfur Cells: The Gap between the State-of-the-Art and the Requirements for High Energy Battery Cells. Adv. Energy Mater. 2015, 5. [CrossRef]

23. Gao, J.; Lowe, M.A.; Kiya, Y.; Abruña, H.D. Effects of liquid electrolytes on the charge-discharge performance of rechargeable lithium/sulfur batteries: Electrochemical and in-situ X-ray absorption spectroscopic studies. J. Phys. Chem. C 2011, 115, 25132-25137. [CrossRef]

24. Pang, Q.; Liang, X.; Kwok, C.Y.; Kulisch, J.; Nazar, L.F. A Comprehensive Approach toward Stable Lithium-Sulfur Batteries with High Volumetric Energy Density. Adv. Energy Mater. 2017, 7, 1601630. [CrossRef]

25. Thieme, S.; Brückner, J.; Meier, A.; Bauer, I.; Gruber, K.; Kaspar, J.; Helmer, A.; Althues, H.; Schmuckc, M.; Kaskel, S. A lithium-sulfur full cell with ultralong cycle life: Influence of cathode structure and polysulfide additive. J. Mater. Chem. A 2015, 3, 808-3820. [CrossRef] 
26. Zhang, S.S. Liquid electrolyte lithium/sulfur battery: Fundamental chemistry, problems, and solutions. J. Power Sources 2013, 231, 153-162. [CrossRef]

27. Qian, J.; Henderson, W.A.; Xu, W.; Bhattacharya, P.; Engelhard, M.; Borodin, O.; Zhang, J.G. High rate and stable cycling of lithium metal anode. Nat. Commun. 2015, 6, 6362. [CrossRef] [PubMed]

28. Park, M.S.; Ma, S.B.; Lee, D.J.; Im, D.; Doo, S.G.; Yamamoto, O. A highly reversible lithium metal anode. Sci. Rep. 2014, 4, 3815. [CrossRef] [PubMed]

29. Brückner, J.; Thieme, S.; Böttger-Hiller, F.; Bauer, I.; Grossmann, H.T.; Strubel1, P.; Althues, H.; Spange, S.; Kaskel, S. Carbon-based anodes for lithium sulfur full cells with high cycle stability. Adv. Funct. Mater. 2014, 24, 284-1289. [CrossRef]

30. Klöpffer, W.; Grahl, B. Life Cycle Assessment (LCA); Wiley-VCH Verlag GmbH \& Co. KGaA: Weinheim, Germany, 2014.

31. Hauschild, M.Z. Introduction to LCA. In Life Cycle Assessment; Springer: Cham, Switzerland, 2018; pp. 59-66.

32. Hauschild, M.Z.; Huijbregts, M.A.J. Introducing Life Cycle Impact Assessment. In Life Cycle Impact Assessment; Springer: Dordrecht, The Netherlands, 2015; pp. 1-16.

33. Cerdas, F.; Egede, P.; Herrmann, C. LCA of Electromobility. In Life Cycle Assessment; Springer: Cham, Switzerland, 2018; pp. 669-693.

34. Duce, A.D.; Egede, P.; Öhlschläger, G.; Dettmer, T.; Althaus, H.J.; Bütler, T.; Szczechowicz, E. eLCAr-Guidelines for the LCA of Electric Vehicles. Report from project "E-Mobility Life Cycle Assessment Recommendations", funded within the European Union Seventh Framework Programme-FP7/2007-2013; Proj. No. 285571. 31 January. Available online: https://www.elcar-project.eu/download/guidelines/ (accessed on 20 October 2017).

35. Nealer, R.; Hendrickson, T.P. Review of Recent Lifecycle Assessments of Energy and Greenhouse Gas Emissions for Electric Vehicles. Curr. Sustain. Energy Rep. 2015, 2, 66-73. [CrossRef]

36. Hawkins, T.R.; Gausen, O.M.; Strømman, A.H. Environmental impacts of hybrid and electric vehicles-A review. Int. J. Life Cycle Assess. 2012, 17, 997-1014. [CrossRef]

37. Helmers, E.; Marx, P. Electric cars: Technical characteristics and environmental impacts. Environ. Sci. Eur. 2012, 24, 14. [CrossRef]

38. Miotti, M.; Supran, G.J.; Kim, E.J.; Trancik, J.E. Personal Vehicles Evaluated against Climate Change Mitigation Targets. Environ. Sci. Technol. 2016, 50, 10795-10804. [CrossRef] [PubMed]

39. Yong, J.Y.; Ramachandaramurthy, V.K.; Tan, K.M.; Mithulananthan, N. A review on the state-of-the-art technologies of electric vehicle, its impacts and prospects. Renew. Sustain. Energy Rev. 2015, 49, 365-385. [CrossRef]

40. Messagie, M.; Macharis, C.; Van Mierlo, J. Key outcomes from life cycle assessment of vehicles, a state of the art literature review. In Proceedings of the 2013 World Electric Vehicle Symposium and Exhibition (EVS27), Barcelona, Spain, 17-20 November 2013; pp. 1-9.

41. Jungmeier, G.; Dunn, J.B.; Elgowainy, A.; Ozdemir, E.D.; Ehrenberger, S.; Althaus, H.J.; Widmer, R. Life cycle assessment of electric vehicles-Key issues of Task 19 of the International Energy Agency (IEA) on Hybrid and Electric Vehicles (HEV). In Proceedings of the 2013 World Electric Vehicle Symposium and Exhibition (EVS27), Barcelona, Spain, 17-20 November 2013; pp. 1-7.

42. Hofer, J. Sustainability Assessment of Passenger Vehicles: Analysis of Past Trends and Future Impacts of Electric Powertrains; ETH Zurich: Zürich, Switzerland, 2014.

43. Bauer, C.; Hofer, J.; Althaus, H.-J.; Del Duce, A.; Simons, A. The environmental performance of current and future passenger vehicles: Life cycle assessment based on a novel scenario analysis framework. Appl. Energy 2015, 157, 871-883. [CrossRef]

44. Messagie, M.; Boureima, F.S.; Coosemans, T.; Macharis, C.; van Mierlo, J. A range-based vehicle life cycle assessment incorporating variability in the environmental assessment of different vehicle technologies and fuels. Energies 2014, 7, 1467-1482. [CrossRef]

45. Helmers, E.; Dietz, J.; Hartard, S. Electric car life cycle assessment based on real-world mileage and the electric conversion scenario. Int. J. Life Cycle Assess. 2017, 22, 15-30. [CrossRef]

46. Egede, P. Environmental Assessment of Lightweight Electric Vehicles; Springer: Cham, Switzerland, 2017; pp. 94-98.

47. Deng, Y.; Li, J.; Li, T.; Gao, X.; Yuan, C. Life cycle assessment of lithium sulfur battery for electric vehicles. J. Power Sources 2017, 343, 284-295. [CrossRef] 
48. Notter, D.A.; Gauch, M.; Widmer, R.; Wäger, P.; Stamp, A.; Zah, R.; Althaus, H. Contribution of Li-Ion Batteries to the Environmental Impact of Electric Vehicles. Environ. Sci. Technol. 2010, 44, 6550-6556. [CrossRef] [PubMed]

49. Zackrisson, M.; Avellán, L.; Orlenius, J. Life cycle assessment of lithium-ion batteries for plug-in hybrid electric vehicles-Critical issues. J. Clean. Prod. 2010, 18, 1519-1529. [CrossRef]

50. Dunn, J.B.; Gaines, L.; Sullivan, J.; Wang, M.Q. Impact of recycling on cradle-to-gate energy consumption and greenhouse gas emissions of automotive lithium-ion batteries. Environ. Sci. Technol. 2012, 46, 12704-12710. [CrossRef] [PubMed]

51. Peters, J.; Buchholz, D.; Passerini, S.; Weil, M. Life cycle assessment of sodium-ion batteries. Energy Environ. Sci. 2016, 9, 1744-1751. [CrossRef]

52. Schünemann, J.H.; Wissenschaft, F.; Praxis, I.F. Modell zur Bewertung der Herstellkosten von Lithiumionenbatteriezellen; Sierke: Göttingen, Germany, 2015.

53. Yuan, C.; Deng, Y.; Li, T.; Yang, F. Manufacturing energy analysis of lithium ion battery pack for electric vehicles. CIRP Ann. Manuf. Technol. 2017, 66, 53-56. [CrossRef]

54. Diekmann, J.; Hanischb, C.; Frobösea, L.; Schälickea, G.; Loellhoeffela, T.; Fölstera, A.; Kwadea, A. Ecological Recycling of Lithium-Ion Batteries from Electric Vehicles with Focus on Mechanical Processes. J. Electrochem. Soc. 2017, 164, A6184-A6191. [CrossRef]

55. Gallagher, K.G.; Nelson, P.A. Manufacturing Costs of Batteries for Electric Vehicles; Elsevier: Amsterdam, The Netherlands, 2014.

56. Hanisch, C.; Haselrieder, W.; Kwade, A. Recycling von Lithium-Ionen- Batterien-Das Projekt LithoRec. In Recycling und Rohstoffe; Thomé-Kozmienski, D.G.K.J., Ed.; TK Verlag: Neuruppin, Germany, 2012; pp. 691-698.

57. Kwade, A.; Diekmann, J.; Hanisch, C.; Spengler, T.; Thies, C.; Herrmann, C.; Dröder, K.; Cerdas, F.; Gerbers, R.; Scholl, S.; et al. Recycling von Lithium-Ionen-Batterien-LithoRec II Abschlussberichte der beteiligten Verbundpartner. Verbundprojekt im Rahmen des Förderprogramms, Erneuerbar Mobil “des Bundesministeriums für Umwelt, Naturschutz, Bau und Reaktorsicherheit. 2016. Available online: https:/ / www.erneuerbar-mobil.de/sites/default/files/2017-01/Abschlussbericht_ LithoRec_II_20170116.pdf (accessed on 20 October 2017).

58. Hanisch, C.; Loellhoeffel, T.; Diekmann, J.; Markley, K.J.; Haselrieder, W.; Kwade, A. Recycling of lithium-ion batteries: A novel method to separate coating and foil of electrodes. J. Clean. Prod. 2015, 108, 301-311. [CrossRef]

59. Hanisch, C.; Diekmann, J.; Stieger, A.; Haselrieder, W.; Kwade, A. Recycling of Lithium-Ion Batteries. In Handbook of Clean Energy Systems; John Wiley \& Sons, Ltd.: New York, NY, USA, 2015; pp. 1-24.

60. Cerdas, F.; Andrew, S.; Thiede, S.; Herrmann, C. Disassembly Planning and Assessment of Automation Potentials for Lithium-Ion Batteries. In Recycling of Lithium-Ion Batteries the Lithorec Way; Springer: Cham, Switzerland, 2018; pp. 83-97.

61. Cerdas, F.; Andrew, S.; Thiede, S.; Herrmann, C. Environmental Aspects of the Recycling of Lithium-Ion Traction Batteries. In Recycling of Lithium-Ion Batteries the Lithorec Way; Springer: Cham, Switzerland, 2018; pp. 267-288.

62. Ecoinvent Centre. Ecoinvent. 2015. Available online: http://www.ecoinvent.org/ (accessed on 20 October 2017).

63. Goedkoop, M.J.; Heijungs, R.; Huijbregts, M.; De Schryver, A.; Struijs, J. Recipe 2008: A Life Cycle Impact Assessment Method Which Comprises Harmonised Category Indicators at the Midpoint and the Endpoint Level. First Edition Report I: Characterisation. Available online: https:/ /www.leidenuniv.nl/cml/ssp/ publications / recipe_characterisation.pdf (accessed on 20 October 2017).

64. Del Duce, A.; Gauch, M.; Althaus, H.-J. Electric passenger car transport and passenger car life cycle inventories in ecoinvent version 3. Int. J. Life Cycle Assess. 2016, 21, 1314-1326. [CrossRef]

65. Granta Design Limited. CES Selector Software; Granta Design Limited: Cambridge, UK, 2013.

66. World Health Organisation. N-Methyl-2-Pyrrolidone; World Health Organisation: Geneva, Switzerland, 2001.

67. Wood, D.L.; Li, J.; Daniel, C. Prospects for reducing the processing cost of lithium ion batteries. J. Power Sources 2015, 275, 234-242. [CrossRef]

68. Ludwig, B.; Zheng, Z.; Shou, W.; Wang, Y.; Pan, H. Solvent-Free Manufacturing of Electrodes for Lithium-ion Batteries. Sci. Rep. 2016, 6, 23150. [CrossRef] [PubMed] 
69. Thieme, S.; Brückner, J.; Bauer, I.; Oschatz, M.; Borchardt, L.; Althuesa, H.; Kaskel, S. High capacity micro-mesoporous carbon-sulfur nanocomposite cathodes with enhanced cycling stability prepared by a solvent-free procedure. J. Mater. Chem. A 2013, 1, 9225. [CrossRef]

70. Jeschull, F.; Brandell, D.; Edström, K.; Lacey, M.J. A stable graphite negative electrode for the Lithium-sulfur battery. Chem. Commun. 2015, 51, 17100-17103. [CrossRef] [PubMed]

71. Fu, Y.; Zu, C.; Manthiram, A. In Situ-Formed Li2S in Lithiated Graphite Electrodes for Lithium-Sulfur Batteries. J. Am. Chem. Soc. 2013, 135, 18044-18047. [CrossRef] [PubMed]

72. Peters, J.; Weil, M. A Critical Assessment of the Resource Depletion Potential of Current and Future Lithium-Ion Batteries. Resources 2016, 5, 46. [CrossRef]

(C) 2018 by the authors. Licensee MDPI, Basel, Switzerland. This article is an open access article distributed under the terms and conditions of the Creative Commons Attribution (CC BY) license (http:/ / creativecommons.org/licenses/by/4.0/). 